\title{
How to Develop Blended Learning Educational Evaluation Courses Islamic Religious Education Study Program
}

\author{
Ismail Marzuki*, Zulfiati Syahrial, Rusmono \\ Department of Education Technology, State University of Jakarta, Indonesia
}

Received October 24, 2019; Revised January 21, 2020; Accepted February 25, 2020

Copyright $\bigcirc 2020$ by authors, all rights reserved. Authors agree that this article remains permanently open access under the terms of the Creative Commons Attribution License 4.0 International License

\begin{abstract}
The aim of this study is to develop a blended learning educational evaluation course for Islamic Religious Education study program. Educational technology is the study and ethical practice of facilitating learning and improving performance through the creation, use and management of technological processes and resources in an appropriate manner. In this scenario, the role of the educators cannot be denied. The role of educators can be highlighted more by adopting the Indonesian National Qualification Framework (KKNI) curriculum and the National Higher Education Standards. Therefore, this research aimed at developing a blended learning educational evaluation course for Islamic Religious Education study program. The method used in this study includes a type of research and development $(\mathrm{R} \& \mathrm{D})$. This research produces blended learning that can be utilized by students. This research was carried out in the Islamic Religious Education Study Program (PAI) of the Faculty of Islamic Religion (FAI) of the University of Muhammadiyah Tangerang, which is located on Jalan Perintis Kemerdekaan No. 1/33 Cikokol Kota Tangerang Banten. The results of this study showed that the blended learning evaluation course can contribute positively to the progress of the institution and the conducive educational climate in the Faculty of Islamic Religion of the University of Muhammadiyah Tangerang in particular Islamic religious education study programs, specifically in learning education evaluation courses and generally learning other subjects.
\end{abstract}

Keywords Blended Learning, Evaluation, PAI, R \& D

\section{Introduction}

Improving the quality of education certainly cannot be separated from the learning process. The learning process is an essential activity in education. Renewal needs to be done to improve the quality of education that is preceded by a learning process. The learning process is essentially a communication process in which there are various activities, one of which is the delivery of learning material.

Starting with an understanding of educational technology, Januszewski \& Molenda (2008: 1) The Association of Education Communication \& Technology (AECT) defines: "Educational technology is the study and ethical practice of facilitating learning and improving performance by creating, using, and managing appropriate technological processes and resources ". (Januszewski, A. \& Molenda, 2008) Based on the above definition, Educational technology is the study and ethical practice of facilitating learning and improving performance through the creation, use and management of technological processes and resources in an appropriate manner.

Currently, the role of educators has been replaced by the latest educational technology products, such as audio, video, audio video and even the internet, but the role of educators as models (models) that stimulate the development of hidden potential learners will never be replaced. The target in education is not only reason (cognitive), but also attitude (affective). Although part of the role of education has been replaced with technology products, the image of educators must remain good and can be done if the educator compensates by continuing to improve the four aspects of competence, namely pedagogical competence, personal competence, social competence, and professional competence.

The demands for the role of educators in education are more visible with the adoption of the Indonesian National Qualification Framework (KKNI) curriculum and the National Higher Education Standards. Educational Evaluation courses given in the sixth semester Bachelor 
level (S-1) Islamic Religious Education Study Program (PAI) Faculty of Islamic Religion (FAI) University of Muhammadiyah Tangerang (UMT) have the aim that students are able to: (1) understand the general picture of evaluation education, (2) understand the types and processes of educational evaluation, (3) understand the concept of Taxonomy of objectives and evaluating learning outcomes, (4) understand competency-based assessment, (5) understand the forms and techniques of evaluating learning outcomes, (6) understand and planning tests, lattices -test and item analysis, (7) understand the scoring techniques and scoring system, (8) understand the processing techniques and evaluation results scores, (9) understand and apply test validity and reliability, (10) understand standard and non-standard tests, (11) analyze the results of evaluations, (12) understand the techniques of making questions, and (13) understand the use of evaluation results. (Fauzi, 2017)

According to the objectives of education evaluation courses, the PAI study program clearly implied that to achieve an understanding or results maximally requires a learning model that is able to facilitate so that a good understanding is reached so that students have mature knowledge and experience in the evaluation subject education both theory and practice.

Educational evaluation courses are compulsory subjects that must be taken by PAI FAI UMT study program students with a study load of 2 SKS. The course provides students with very basic practical skills as prospective educators, especially PAI educators in learning evaluation activities, namely education measurement and assessment techniques, test formulation and learning outcome test techniques, validity testing techniques and test results reliability and item analysis techniques question.

Based on preliminary observations through interviews conducted on April 15, 2019 with ten active students in the sixth semester of the PAI FAI UMT study program, it is shown that the difficulties faced by students when carrying out educational evaluation courses are (1) the unfinished discussion of the material optimally because of the broad material coverage. This causes some material to be left behind / not discussed so that students have difficulty repeating learning material. (2) Learning is carried out face-to-face in the lecture room (classroom), namely by the lecture method and group presentations which are carried out monotonously so as to cause a sense of boredom for students. (3) In some educational evaluation materials that have the characteristics of calculating as well as finding validity and reliability, values are the main difficulties in learning educational evaluation, and (4) educational evaluation courses required some material that must be implemented with direct practice such as practice of measurement techniques and educational assessment, test formulation and learning achievement test techniques, validity and reliability test techniques for learning outcome tests and item analysis techniques.

Furthermore, when viewed in more depth based on the theory of the learning method, the lecture method is a method of giving a description or explanation to a number of students at a certain time and place. Furthermore, Majid (2013: 194) states that lecture as a learning method is a method used in developing the learning process through speaking (Majid, 2013). Then Syfa (2014: 81) states the lecture learning method is verbal illumination of learning material to a group of listeners to achieve certain learning goals in a relatively large amount. (Syfa S., 2014) Therefore, it can be revealed that the face-to-face method is a teaching method where educators teach by delivering information and knowledge to achieve certain learning goals to a number of students at a certain time and place.

The application of the face-to-face method itself has advantages and disadvantages. The advantages of the faceto-face method are that it can convey information quickly, the material provided is unraveled clearly and it can be used in a large number of student learning plans. Then the weakness of the face-to-face method is that it requires a good listening and listening ability which means that the face-to-face method can only take place well if students have good listening and listening skills. The face-to-face method emphasizes one-way communication where to control students' understanding of learning material is very limited, one-way communication can result in students' understanding or knowledge being limited to what is given. The face-to-face method is not possible to serve differences in abilities, differences in knowledge, interests, talents and differences in learning styles.

E-learning, according to Pegler \& Littlejohn (2007: 3), is an increasingly important skill for effective learning, but still challenging for most educators in tertiary and further education. There are four main reasons, namely: (1) learners increasingly expect the application of effective technology; this can intimidate educators who are beginners in using this technology themselves, (2) educators are under time pressure, educators need to understand how to design the right mix of online and offline, if not, students are likely to work unproductively, (3) the program needs to be made on an ongoing basis, so that learning material can be easily produced, stored, retrieved, and reused, and (4) Educators are certainly not sure about how to invest their time and efforts in fast movements. (Pegler, C., \& Littlejohn, 2007)

Although e-learning can be used independently by students, but the existence of educators becomes very meaningful as someone who has the role of providing support and assisting students in the learning process. In other words, the face-to-face process is important and cannot be abandoned in learning.

The fact shows that until now the results of educational evaluation studies have not shown maximum or satisfying results. Factors causing difficulties for students in learning 
education evaluation courses, because the characteristics of educational evaluation itself are some of the concepts generally mathematical. Other factors that cause weaknesses in educational evaluation learning are the habit of only applying the monotonous lecture and group discussion methods in the implementation of learning and the lack of the ability of educators to present the right approach or learning strategy to motivate students and involve them in the learning process. The lecture method according to Bligh (2008: 88) states that the lecture is "continuous expositions by a speaker who wants the audience to learn something" which means that the lecture is a continuous exposure by the speaker who wants the audience to learn something. From the understanding of the lecture method reveals that lectures are identical with instructional centered learning (Instructor Centered Method). (Zaini, H. Bermawy, 2008) According to Silberman (2006: 46) the lecture method will not deliver on effective learning, because it must first arouse interest, maximize understanding and remembrance. (Silberman, 2006).

The gap between expectations and the reality encountered at the time of initial observation needs to be addressed immediately. The existence of a blanded learning model with the aim of facilitating the learning process in educational evaluation courses is expected to be able to deliver students' understanding of these courses even though the learning styles of each student are different. This is in line with the phrase given by Danchak (2004) "Some individuals need concrete experiences while others are more comfortable with abstract concepts. It is not practical to tailor a single lecture exclusively to the learning style of each participant. (Hassana, Ruba Abu \& Woodcock, 2014). States that some individuals need concrete experiences while others are more comfortable with abstract concepts. It is not practical to adapt one lecture exclusively to the learning styles of each participant.

This condition is seen as a form of weakness in the implementation of the learning process of educational evaluation courses. Therefore, to address this it is necessary to do innovation in the learning process as a response to the symptoms of weakening the quality of the process, lack of understanding and learning outcomes of educational evaluation courses.

Among the existing learning models, there are models that have advantages in solving learning problems and bringing students to be more effective in learning (effective learners). One learning model that needs to be considered is blended learning. Blended learning has several main variations namely off line and on line based learning. It's actually more than just combining face-to-face learning with online learning. Watson (2008) This blended approach combines the best elements of online and face-to-face learning. (Watson, 2008). States that blended learning is basically a combination of the best elements of face-to-face learning with the best elements of online learning.

\section{Literature Review}

\subsection{Blended Learning}

Stein \& Graham (2014: 12) states that blended learning is a combination of face-to-face and online activities to produce effective, efficient, and flexible learning. Blended learning is one of the right solutions to make learning to be suitable not only for learning needs, but also for students' learning styles. (Stein, J. \& Graham, 2014)

Anis Chaeruman, Wibawa \& Syahrial (2018: 189) states that blended learning comes from a term known as elearning. Blended learning is a general term used as an umbrella for any terms such as virtual learning, online learning, virtual classrooms, mobile learning, and so on. The authors define e-learning differently. Researchers define e-learning as learning made possible by electronic technology (Anis Chaeruman, Wibawa, \& Syahrial, 2018).

Blended learning, according to Garrison and Kanuka, at its simplest, blended learning is the thoughtful integration of classroom face to face learning experiences with online learning experiences" in Aeni, Concerned \& Utanto, (2017: $85)$. Therefore, blended learning is an integration of faceto-face learning with online learning. Blended learning is described as a model for learning where educators utilize technology, usually in filling in web-based instructions, daily tasks, or allowing as instructor's main instructions (Aeni, Concerned, \& Utanto, 2017).

Educators play an important role in improving the quality of students in learning and educators must really pay attention, think about and at the same time plan an interesting learning process for students, so that students are interested and enthusiastic about learning to be involved in the learning process, so that learning becomes effective. To create effective learning an educator must use many methods, while the methods and resources consist of media and learning materials

\subsection{Concept Development Model}

Learning technology seeks to design, develop and utilize a variety of learning resources so that it can facilitate or facilitate a person to learn anywhere, anytime, by anyone, and by whatever learning methods and resources that suit their conditions and needs. The existence of learning technology with a view to solving learning problems or facilitating learning activities. Learning technology as software (software technology) in the form of systematic ways in solving learning problems is increasingly sophisticated and has a broad place in the world of education, especially in designing and making learning systems. The components contained in the design of learning systems are usually described in the bentul model which is represented in the form of graphics or flow charts.

According to Morrison, Ros and Kemp (2001: 23), learning system design models will be able to help 
educators as program designers or learning activities in understanding the theoretical framework better and applying theories to create more effective and efficient learning activities. Some experts argue about the notion of the model. Henson (2015: 156) defines the model as a series of quantitative and qualitative logic that connects relevant aspects of real life. (Henson, 2015) The model can organize what is already known, help see new relationships, and help avoid ignorance resulting from the complexity of an object. Then according to Davies (1996: 24) the model as a more specific and more detailed representation of reality. (Davies, 1996) Then according to Benny (2010: 86) the model is a description of steps or procedures that need to be taken to create effective learning activities, efficient and attractive. (Benny, 2010) Meanwhile, according to Gustafson and Branch (1997: 1) defines the model as "a simple representation of more complex forms, processes, and functions of physical phenomena or ideas" which means that the model is a simple representation of physical form, process, and function of a more complex phenomenon (Gustafson, KL, \& Branch, 1997). From some understanding of the model according to the experts above, it can be stated that the model is a logical quantitative or qualitative series that connects relevant aspects that are useful for seeing new relationships, avoiding ignorance caused by the complexity of the object so that it can make representations that are more specific and more detailed.

Related to the model developer, according to J. Rothwell and HC Kazanas (2004: 3) states that "instructional design means more than literally creating instruction" which means that instructional design is more than just creating learning. This relates to the broader concept of systematically analyzing human performance problems, identifying the root causes of problems, considering various solutions to overcome the root causes, and implementing solutions in ways designed to minimize the unintended consequences of remedial actions.

\subsection{The Concepts of Learning}

The concept of 'learning' is not exactly the same as the concept of 'learning' even though both of them have quite close links. Learning is a student's activity to get information, knowledge and experience. Learning is also an interactive and structured activity between educators and students to achieve a change. Of course the expected change is a change that is more positive, not negative.

The term learning is actually used to emphasize that learning interactions, especially in the classroom, between educators and students are dynamic. This term is also intended to perfect the teaching term which emphasizes the active role of educators, whereas students tend to take for granted what the educator has said. Learning strongly emphasizes the process of interaction and optimal use of learning resources.

Reigult and Chellman (2009: 6) states that learning is everything that is done with the aim to facilitate learning.
Then Djikstra and Leemkuil (2008: 190) revealed that learning is an activity to make that goal possible and easily achieved. From these notions it can be stated that learning is a process carried out with a learning facility to achieve learning goals so that it is easily achieved.

\section{Research Methodology}

This research uses a model development method. This type of research used is a type of development research. According to Sugiono (2008: 297), Research and Development Method (Research and Development) is a research method used to produce certain products, and test the effectiveness of these products. To be able to produce these products, a needs analysis study is needed and to test the effectiveness of the product in order to function in education, research is needed to test the effectiveness of the product. (Sugiyono, 2008).

Research and development steps for Blended Learning Educational Evaluation Courses Islamic Religious Studies Program uses two models of the 4th \& 4th Borg Cycle R \& $D$ by taking the first step, namely collecting data and information, and combined with the Step of System Approach Model of the 8th edition of Gall, Gall \& Borg Research and Development which adopted the Systemic Design of Instruction model (Dick, Carey, \& Carey).

In Research and Development (Research and Development), the model to be developed is the Development of Blended Learning in Educational Evaluation Courses for Islamic Religious Education Study Programs. Explanation of the characteristics of the model to be developed are as follows:

a. Characteristics of the Blended Learning Model

Regarding the characteristics of the developed model related to blended learning, the following characteristics of blended learning are described:

- Learning that combines various ways of delivery, learning models, learning styles, as well as a variety of diverse technology-based media.

- As a combination of direct learning (face to face), independent learning, and independent learning via online.

- Learning is supported by an effective combination of delivery methods, teaching methods and learning styles.

- Educators and parents (guardians) of students have the same important role, educators as facilitators, and parents (guardians) as supporters.

b. Characteristics of Subjects of Educational Evaluation With regard to the characteristics of the models developed related to the subject of educational evaluation, research was conducted in Study Program of Islamic Education (PAI) Faculty of Islamic Studies (FAI) University of Muhammadiyah Tangerang, beginning with a preliminary study in April 2019 Semester Year Academic 2018/2019 which passed in the path of the Pioneer of 
Independence No. 1/33 Cikokol Kota Tangerang - Banten. Development research is planned from September 2019 to February 2020. Furthermore, the effectiveness of the results of development products will be testedt in March to May 2019.

\section{Research Results}

\section{a. Draft 1 model}

Development of draft 1 is based on the results of goal identification and analysis of learning objectives. Identification and analysis of this need is done after analyzing the results of preliminary research that has been done before. Draft 1 was made after determining General Instructional Objectives, learning analysis, identifying behaviors and initial characteristics, Specific Instructional Objectives, reference assessment and learning strategies. Then the design experts and material experts are tested. This draft eventually becomes a book or learning module, in which in addition to learning material it also contains examples of questions whose contents have been validated and revised according to expert advice. Making a draft written about the mapping results that already exist in the learning objectives. Existing mapping planned pouring in the form of menus contained in e-learning that was developed.

\section{b. Draft Model 2}

Draft 2 is an explanation of the components, subcomponents that are input into the final draft. This draft 2 relates to the media used in the learning process namely blended learning. Therefore, it takes several things, namely:

\section{1) Overview of general needs}

\section{a) Hardware and software}

In the process of making e-learning assisted learning materials it is recommended to use a minimum of $1.8 \mathrm{GHz}$ Pentium IV Hardware processor, 512 MB RAM memory, SVGA / XGA memory resolution 1024 x 768. Software recommended at least Windows XP operating system, Vista, Seven, Internet Explorer 6.0 browser or above or Firefox 3.0.

b) The user administrator and operator and user (user)

2) Preparation of the main page contains a lecturer profiles, materials and quizzes as well as login. Next will log in by:

a) entering the user name with the user name.

b) provide a password that has been determined by the admin.

c) Provisions: Admin and operators

This section can be accessed by the administrator in entering data, edit or delete, add users, add user rights, fill out announcements and so on. Administrators can also access the part that is entitled to students as users, but not vice versa. Students who can access the parts that have been determined by the admin.

\section{Users}

- $\quad$ Direct users:

Students who access directly according to their username and password.

- Users with access:

Users with direct access and have the right to access data after obtaining admin permission.

3) Explanation of the menu on the website

a) Layout of the Menu

Layout on a regular basis can make it easier to understand the function and usefulness of each menu there. The menu is a guideline or guide for developing learning navigation that will be developed aided by e-learning. The menu describes the parts that constitute the main menu and complementary menus.

b) The usefulness of each menu menu on the main page consists of:

- Home is the front view position

- Login (top right corner), is a facility to enter the learning program.

After logging in there will be navigation as follows:

- Home

The home menu serves as a guide to returning to the main page.

\section{- ProfilesProfiles}

The menu functions as an explanation of the lecturer profile.

\section{- $\quad$ Material and Quiz Material and Quiz}

The Menu contains Semester Learning Plans and provides convenience in determining general learning objectives so that they do not deviate from the established curriculum, in addition to the material and quiz menus there are 4 sub menus including:

\section{- $\quad$ Pre-test}

Menu Pre-test is a menu containing test questions before entering learning material.

- Material

Menu Material is a menu containing a collection of material from meeting 1 to meeting 14 in which (in each meeting) there are lecture modules in the form of MS Word online, lecture presentations in the form of power points, quizzes in the form of two types namely choice types double and true and false types and the last is a learning 
video available at each meeting.

- Post-test

Menu Post-test is a menu that contains test questions after previously following a series of learning materials both face-to-face and online learning.

- $\quad$ Forum

Discussion menu is a menu for interactive lecturers and students and students.

- Logout

Is a menu to exit the program.

\section{Model Feasibility}

a. One to One Expert Test

\section{1) Learning Design Expert}

Thefeasibility of blended learning in educational evaluation is known by validation by the learning design expert. Expert validation is needed to determine the feasibility of products developed in terms of development procedures such as the accuracy of the formulation of TIU, the relevance of the strategies used, the quality of learning materials, designing, e-learning as a source of learning and their attractiveness and accuracy. The above is examined in terms of the application of the principles of educational technology.

Based on the validation of learning design experts, overall that the quality of draft 1 and 2 learning materials of blended learning education evaluation courses is at a 3.88 or $77.83 \%$ suitability level. This figure is in the good assessment stage.

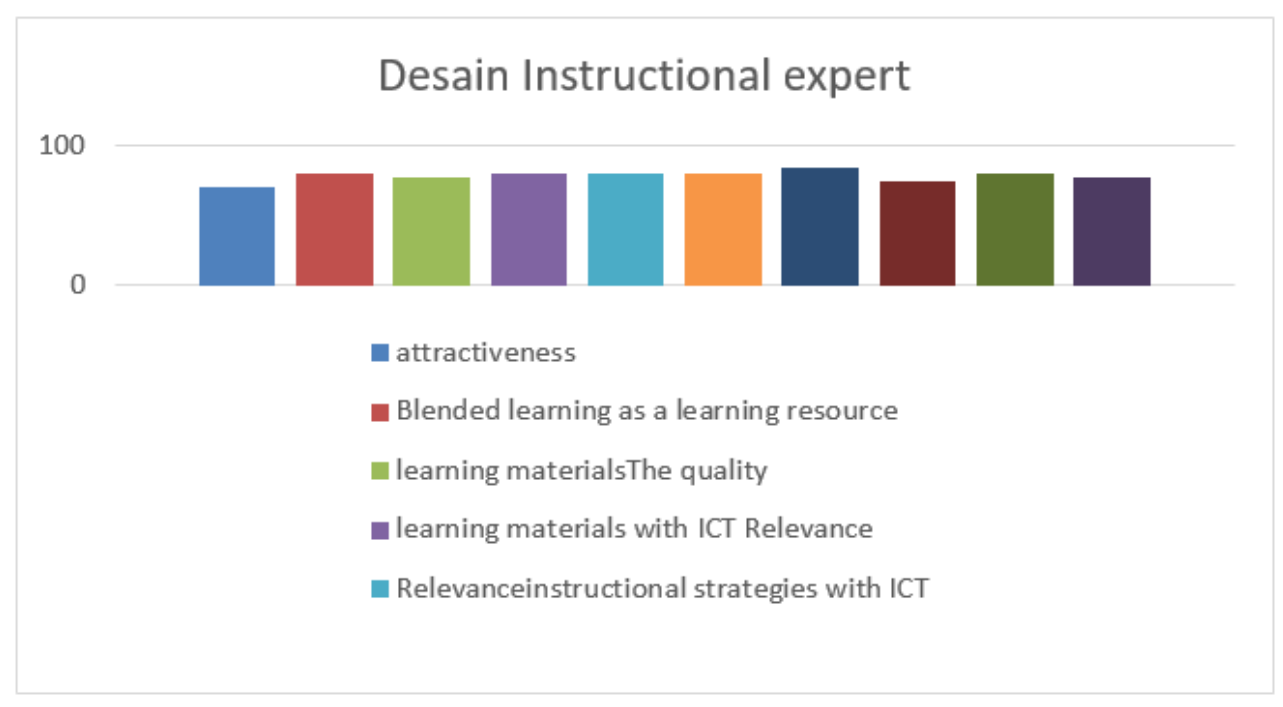

Figure 1. Learning Design Expert Results 


\section{2) Material Expert}

Feasibility test by the material expert was carried out in the draft of blended learning educational evaluation taken from the assessment of indicators, namely (1) the truth and feasibility of the material with scientific study, (2) the use of language and sequence of materials, (3) presentation of material and participation student learning, (4) clarity and accuracy of learning outcomes assessment instruments.

The results of the validation by the material experts are outlined in the following graphic form:

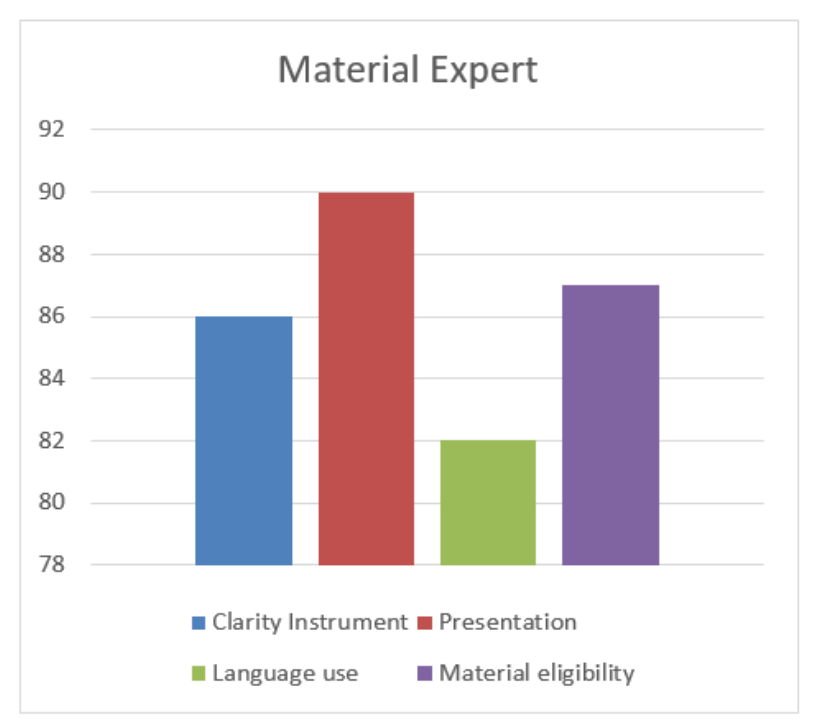

Figure 2. Results of Expert Validation

Based on figure 2 above can be informed:

a) The truth and appropriateness of the material with scientific studies.

The results of the validation by material experts on this indicator show a level of conformity of 4.29 or $86 \%$, which means that it is included in the excellent category. These results indicate that the draft of blended learning learning material for educational evaluation courses is appropriate.

b) Use of language and material sequence.

Indicators of language use and sequence of materials used indicate the level of conformity in either category, with an average of 4.00 or $80 \%$. This means that the discussion and sequence of material in accordance with applicable rules. Suggestions from material experts so that writing is more adapted to Indonesian spelling that is good and right.

\section{c) Presentation of material and student learning participation.}

The results of validation on this indicator are included in the excellent category, namely the suitability level of 4.60 or $92 \%$. This means that material and user participation are appropriate to use. The matter suggested by material experts so that students can be facilitated by an interactive process online.

d) Clarity and accuracy of learning achievement assessment instruments.

Expert assessment of the material on indicators of clarity and appropriateness of instruments for evaluating learning outcomes is included in either category, with an average of 4.00 or $80 \%$. This means that clarity and accuracy of the assessment instruments can be used.

The results of the first validation by the material expert as a whole towards the development of blended learning learning materials in educational evaluation courses are included in the excellent category with an average suitability of 4.23 or $84 \%$. However, it needs improvement for certain indicator items.

\section{3) Media Expert}

Validation by the media expert is carried out together with validation by the learning design expert and the material expert validation. The validation of learning media is carried out 2 times and is taken based on assessment indicators, namely (1) the attractiveness of the display, (2) letters and writing, (3) the level of interaction of learning assisted by e-learning, (4) display graphics, (5) completeness blended learning learning educational evaluation courses

The results of the first validation by the media experts on the draft $b$ learning blended learning education evaluation courses are outlined in the form of Figure 3 follows: 


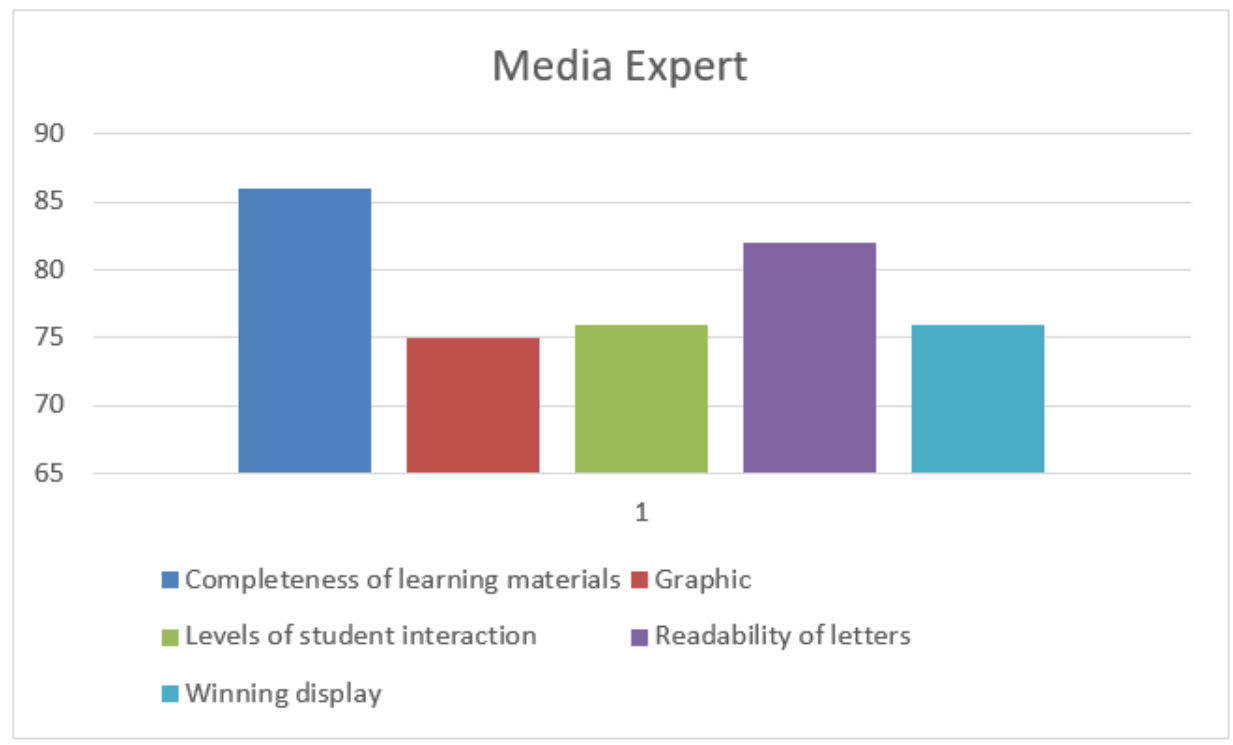

Figure 3. Results of Media Expert Validation

Description of figure 3 is contained in the explanation below:

a) The attractiveness of the appearance

Assessment of media experts about the attractiveness of the display is included in either category with an average of 3.89 or $78 \%$. Media names are appropriate. The appearance of learning media needs to be made more attractive. The appearance of the theme and the ease of operating the navigation are also easy to understand.

But it needs a color selection that can make the media more attractive. Images also need to be added in the media.

\section{b) Letters and Writing}

Letters and writing on blended learning in educational evaluation courses are rated well by media experts with an average of 4.00 or $80 \%$. But the use of various fonts needs to be minimized in the media used.

c) The level of learning interaction

Expert judgment on this indicator is included in either category at an average of 3.88 or $77.5 \%$. According to experts, the ease of chatting, the process of discussion, downloading and uploading is good with adequate operating speeds. Besides assigning guidelines, it is easy to understand so students can work on assignments according to instructions. But it needs to be complemented by the lack of media objects in order to increase multimedia capacity in blended learning in educational evaluation courses.

\section{d) Display graphics}

The expert assessment results on display graphics indicators give values with an average of 3.50 or $70 \%$. This figure is included in both categories. Media experts suggest that there aren't too many types of letters in the media. Dynamic colors should also be made, so that the media display is not monotonous.

\section{e) Completeness of e-learning assisted learning materials.}

The results of the validation of the media experts showed the value in the excellent category with an average of 4.25 or $85 \%$. This means that the completeness of learning materials such as the introduction of each material, the review of each material, the availability of glossaries and reference lists, and evaluations are very good.

Overall, instructional media experts rated this first validation in either category, reaching an average of 3.90 or $78 \%$. Needs to be refined before being tested.

\section{4) One to One Leaner Trial}

This one to one leaner trial is conducted on 3 students who have different abilities in terms of their level of academic ability. Different levels of academic ability are taken from the grades of courses in the previous semester. It is hoped that this development model can accommodate students with different levels of ability.

This individual trial (one to one learner) is assessed based on 3 indicators consisting of the quality of product display, the quality of product presentation, as well as user and program interaction.

As for the quality indicators of product presentation, based on the results of trials, it is found that the average achievement of responses in the excellent category is 4.63 or $93 \%$. These results illustrate that the competencies to be achieved and the learning instructions are clear. The material is easily understood and presented systematically. Test questions range from test instructions, sample questions, to easy-to-understand tests. Summary of available material makes it easy for students to understand the material. E-learning assisted learning is also easy to operate. The conclusion of the results of this trial is that the quality of the presentation of the blended learning material for educational evaluation courses is feasible and can be 
used.

The results of trials on user interaction and the program reached an average of 4.67 or $93 \%$ conformity, including the very good category. User interaction and programs can be seen from the ease with which programs run without the help of others. In addition, users can take advantage of blended learning education evaluation courses anytime and anywhere they are. Users can easily access the material they want to learn. Discussions with lecturers can also be done if there is material that is not understood through the forum. The conclusion that can be drawn from the results of this validation is the blended learning product of the educational evaluation course is feasible and can be used.

Overall trial results obtained an average achievement of 4.72 or $95 \%$ which is included in the excellent category. Based on these results, it can be concluded that the development of the blended learning model of educational evaluation courses is feasible and can be used at every level of student competency.

Development of a blended learning learning model in the educational evaluation course that was tested was quite effective in its application. This can be seen from the achievement of an average of 3 students who validate. Each achieved an average of 4.9 or $98 \%$ for 1 st students, grades of 4.8 or $96 \%$ for 2 nd students, and 4.5 or $90 \%$ for 3 rd students. These three values illustrate that the development of blended learning model of educational evaluation courses is classified in the category of very effectively applied to students with high, medium and low abilities.

\section{5) Field Trial Test}

Field group trial is a step that is carried out after a small group trial. This trial was applied to 20 students with different abilities. Field trial results (Field Trial) can be illustrated in Figure 5 below:

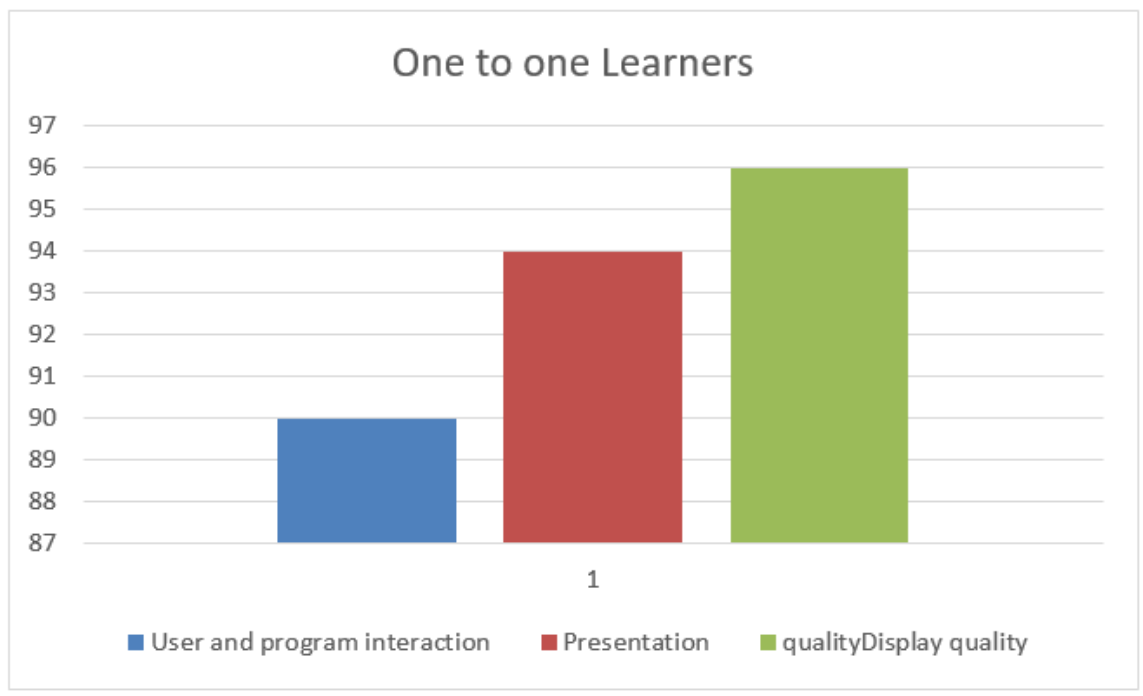

Figure 4. Results of one-on-one trials

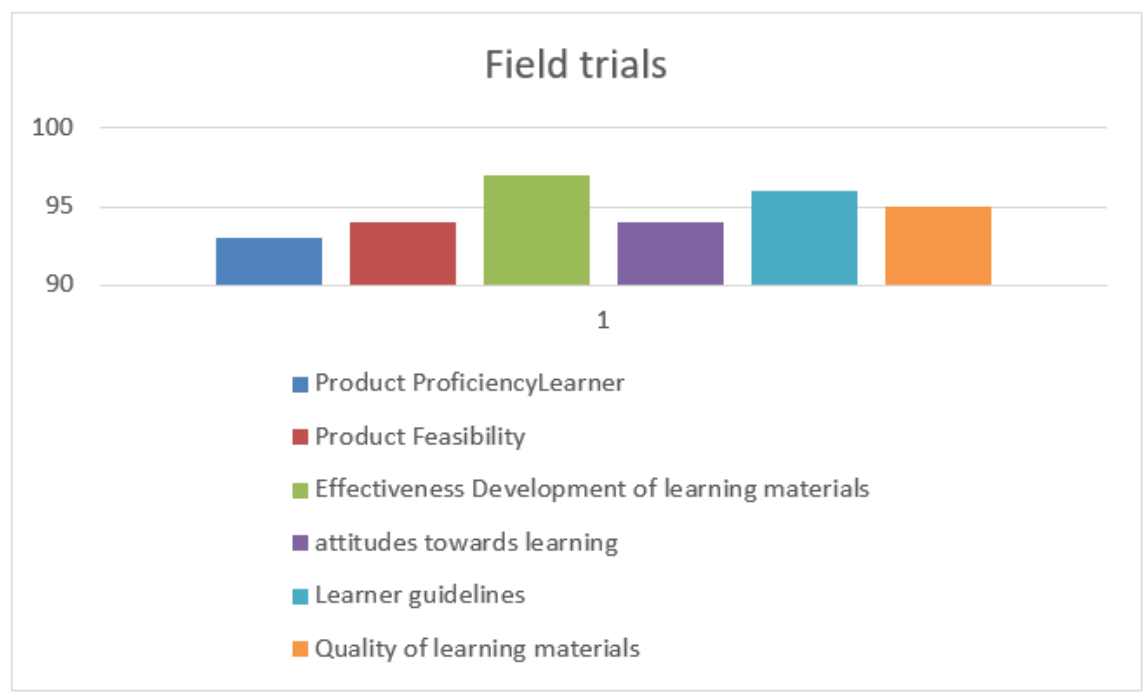

Figure 5. Responses of Field Trial Subjects 
Based on the chart above, we can describe several indicators used in the trial. The first indicator is regarding the quality of the learning process. This indicator scores an average of 4.85 or $97 \%$. This value is in the very good category. These results illustrate that the blended learning process of educational evaluation courses runs effectively and efficiently and is fun for students.

The second indicator is the quality of learning material. This indicator gets an average achievement of 4.71 or $94 \%$ with a very good category. In other words, it can be explained that blended learning learning materials in educational evaluation courses have interesting designs with clear learning objectives. The concepts and definitions that are formulated are clear with language that is easily understood and supported by the existence of simple images and examples. The terms contained in the learning material are also easy to understand because they are presented in the form of facts and data that are consistent with everyday reality.

The next indicator is the learner's and learning guidelines. The chart shows that the indicator reached an average of 4.76 or $95 \%$ including the very good category. Students are greatly helped by the use of the user manual because the words in the manual are easy to understand and make it easier for students to use blended learning in learning, including working on test questions.

This field group trial provides an overview of the achievement of indicators of learners' attitudes towards learning with an average achievement of 4.79 or $96 \%$ with a very good category. This shows the emergence of student motivation in learning blended learning educational evaluation courses because students have a great opportunity to study the material independently wherever they are after the opportunity to face-to-face with lecturers in class. The opportunity to communicate with lecturers and peers is wide open through the forums available on the web. Students also find something new in terms of the upto-date information in learning material because it is presented very complete in the form of online teaching materials, power point slides, up to learning videos, even to daily training. Everything on the web encourages students to learn more often and continuously.

The fifth indicator of field group trials is related to the effectiveness of the development of learning materials. This indicator reaches a very good category with an average of 4.93 or $99 \%$ which means blended learning in educational evaluation courses is more effective in terms of time and more efficient in terms of studying material.

The trial chart above also informs about the achievement of product feasibility indicators with an average value of 4.74 or $95 \%$ with a very good category. This indicates that the product development of learning materials assisted by e-learning can be used in learning and easy to understand because it has concepts, definitions, principles, procedures, and algorithms according to the needs of the subject matter. The material presented is complete and in accordance with
TIU and ICT. The material is presented coherently and systematically accompanied by clarity of examples of proportional practice questions in each learning.

The final indicator of this field group trial is about product updates. An average value of 4.85 or $97 \%$ are in the excellent category. It is said to be very good because the learning material of blended learning in educational evaluation courses has been updated by presenting blended learning learning materials in educational evaluation subjects that are in accordance with developments. The actual drawings and diagrams are presented accompanied by an explanation.

The conclusions from the field group trials as a whole are illustrated by an average achievement of 4.77 or $96 \%$ which fall into the very good category and can be used in everyday life. This is supported by research conducted by Siang, et al (2019). The results of the study show that online learning can improve learning outcomes (Siang, Ibrahim, \& Situmorang, 2019)

\section{Conclusions}

1. The development of the blended learning model of educational evaluation courses is an effort to meet the needs of improving the quality of learning in educational evaluation courses in the Islamic Religious Education study program at the University of Muhammadiyah Tangerang. The procedure for developing a blended learning model of learning evaluation courses has 4 steps in sequence, namely: preliminary research, planning and model development, followed by validation, evaluation, and revision of the model, ending with the implementation of the model.

2. To test the feasibility of a blended learning learning model educational evaluation courses involve learning design experts, material experts, and media experts. Then proceed with one to one trial, and large group trials.

3. Based on the overall assessment of learning design experts, the quality of learning material in blended learning education evaluation subjects is in the very good category. Overall expert assessment of the material, blended learning learning material, educational evaluation courses is included in the excellent category. Blended learning expert media assessment of educational evaluation courses is good and very feasible

4. The results of the one-to-one trial overall are in the excellent category. Based on these results it can be concluded that the development of the blended learning model of educational evaluation courses, is feasible and can be used at every level of student competency. 
5. Overall the results of small group trials with fit in very good categories. This shows that the proposed learning design is very feasible to use.

6. The results of the field group trials are overall in the very good category, which can be used in daily life.

7. The effectiveness of the blended learning model of educational evaluation courses is carried out through pre-test trials obtained an average of 6.23 and an average post-test score of 6.75 , including both categories. To find out whether there is a significant difference in the increase between the pretest and post test, the researchers also tested the significance of the difference in the average pretest and posttest using ttest. $\mathrm{t}$ test results showed that the blended learning model of educational evaluation courses proved to be effective and feasible to use in learning.

\section{REFERENCES}

[1] Aeni, N., Prihatin, T., \& Utanto, Y. (2017). Pengembangan Model Blended Learning Berbasis Masalah pada Mata Pelajaran Sistem Komputer. Innovative Journal of Curriculum and Educational Technology, 6(2), 84-97. https://doi.org/10.15294/ijcet.v6i2.15642

[2] Anis Chaeruman, U., Wibawa, B., \& Syahrial, Z. (2018). Determining the Appropriate Blend of Blended Learning: A Formative Research in the Context of Spada-Indonesia. American Journal of Educational Research, 6(3), 188-195. https://doi.org/10.12691/education-6-3-5

[3] Davies, I. K. (1996). Educational Technology: Archetypes, Paradigms, and Models. In D. P. Ely \& T. Plomp (Eds.), Classic Writings on Instructional Technology. Englewood: Libraries Unlimited.

[4] Fauzi, A. (2017). Kurikulum KKNI Program Studi Pendidikan Agama Islam. Tangerang: Universitas Muhammadiyah Tangerang.

[5] Gustafson, K. L., \& Branch, R. M. (1997). Survey of Instructional Development Models. New York: Clearinghouse on Information \& Technology, Syracuse University.

[6] Hassana, Ruba Abu \& Woodcock, A. (2014). Blended learning: Issues and Concerns. Coventry University: Coventry School of Art and Design.

[7] Henson, K. T. (2015). Curriculum Planning: Integrating Multiculturilsm, Constructivism, and Education Reform (5th ed.). Illinois: Waveland Press.

[8] Januszewski, A. \& Molenda, M. (2008). Educational Technology: A Definition with Commentary. New York: Lawrence Erlbaum Associaties.

[9] Majid, A. (2013). Strategi Pembelajaran. Bandung: Remaja Rosdakarya.

[10] Pegler, C., \& Littlejohn, A. (2007). Preparing for Blended eLearning. New York, USA: Routledge.
[11] Pribadi, B. A. (2010). Model Desain Sistem Pembelajaran. Jakarta: Dian Rakyat.

[12] Siang, J. L., Ibrahim, N., \& Situmorang, R. (2019). Development of hypercontent module using jonnuro model learning desain for candidates master guide. International Journal of Recent Technology and Engineering, 8(2 Special Issue 9), 70-78. https://doi.org/10.35940/ijrte.B1016.0982S919

[13] Silberman, L. M. (2006). Active Learning. Bandung: Nusamedia.

[14] Stein, J. \& Graham, C. R. (2014). Essentials for Blended Learning - A Standars-Based Guide. New York: Routledge.

[15] Sugiyono. (2008). Metode Penelitian Pendidikan, Pendekatan, Kuantitatif, Kualitatif dan R\&D. Bandung: Alfabeta.

[16] Syfa S. (2014). Metode Belajar dan Pembelajaran. Bandung: UPI.

[17] Watson, J. (2008). Blended Learning: The Convergence of Online and Face-to-Face Education. North American Council for Online Learning, 572, 16. https://doi.org/10.1016/j.aca.2006.05.012

[18] Zaini, H. Bermawy, M. A. A. S. (2008). Strategi Pembelajaran Aktif. Yogyakarta: Pustaka Insan Madani. 